\title{
An Initial Readership Survey of Ethiopia
}

A research programme, the Christian Literature Development Project (P.O. Box 2248, Addis Ababa), has been sponsored by the Bible Churchmen's Missionary Society, Globe Publishing House, the Presbyterian Literature Program and Yemissrach Dimts Literature Programme in Ethiopia, and by Christian Literature Fund in Switzerland. Its aim is ' to assess the needs of Ethiopia which can be met by Christian literature in Ethiopian and English languages, to evaluate the extent to which the present programmes minister to these needs, and to make representations for the future dealing with all relevant aspects and in particular production, distribution and methods of training '. Mr. John Conacher, who has been in Ethiopia since 1960 , has conducted about 200 interviews for a readership survey in all except three of the governorate-generals of Ethiopia. The records of these interviews are now being analysed in detail to produce an initial readership survey, intended primarily for the sponsors of the Project, but which will also be made available to other institutions and persons. The scope of the Survey extends to all types of books in any language, and in addition to those in Amharic and English reference will be made to books which those interviewed have read in Tigrinya, Giiz, Kunama, French, and Russian.

\section{The Institute for Development Research, Copenhagen, Denmark}

ThE Institute for Development Research (s, Sct. Annae Plads, DK-I 250, Copenhagen K.) was established in 1968 to undertake, promote, and publish research into the economic and social development of the developing countries, including investigation and evaluation of the development assistance of Denmark and other countries. It is an independent institution, receiving an annual grant from the Danish Government, and governed by a research council of twenty members which met for the first time in March 1969. The Institute is at present engaged in formulating its research programme which will be of a multidisciplinary character relating mainly to five countries in Eastern Africa (Uganda, Kenya, Tanzania, Zambia, Malawi), to Ghana and also to India, Pakistan, and Thailand. Among the projects under consideration are : a study of development planning in East Africa; participation in research related to the rural development policy of Tanzania; a survey of the development problems of a sub-national region in Eastern Africa; and an analysis of the cultural development and cultural policy in one or more African states. Professor Thorkil Kristensen has been appointed as general director, and Cand. polit. Knud Erik Svendsen as research director of the Institute.

\section{El Centro de Estudios, Documentación e Información de Africa (CEDIA)}

A CENTRE for African studies in Madrid has been established by the secretariat of the Comisión de Misiones, under the direction of Fr. Manuel Gomez-Pallete, S.J., formerly director of the Colegio Mayor Nuestra Señora de Africa. The centre aims to provide information on all aspects of African life for the benefit of those engaged in research such as political, industrial, and commercial organizations, university personnel, missionaries, doctors, and technicians intending to work in Africa, and for Africans living in Spain. The work of the centre includes the holding of conferences, seminars, and study groups, direction of theses and studies, the carrying out of specialized projects and the preparation of notices, book reviews, documentation, and card indexes and of information for the press. CEDIA has a library of about 6,000 volumes and is now acquiring books and periodicals of specifically African interest. The cards of the 7,500-volume library of the Colegio Mayor Nuestra Señora de Africa are at present being copied for CEDIA. Card indexes of information, documents, and photographs and of the library, arranged by authors, subjects (decimal 
classification), and with geography, ethnology, biography, and bibliography sections, are available. The address of the centre is : CEDIA, José Marañón 3, Madrid (3).

\section{Third African Regional Conference of the International Social Security Association}

The Reports and Documents of the Third African Regional Conference, held in Abidjan from 6 to 14 September 1968, have now been published (African Social Security Series, No. 5, Special Number 1968) by the General Secretariat of the International Social Security Association (154, tue de Lausanne, Geneva). The conference was attended by nearly 100 delegates and observers from 19 African countries, and representatives of the International Labour Organization, World Health Organization, International Confederation of Free Trade Unions, International Organization of Employers, and the Pan-African Trade Union Organization.

Reports and Documents contains the texts of the speeches made at the opening and closing sessions of the conference, and the full texts of all the reports presented on the main themes of 'Social Security and the National Economy in Developing Countries ', 'Prevention of Occupational Risks: Principles and Methods', and the reports of the African Regional Committees on family allowances, medical care, and rehabilitation; general questions of social security administration; and old age, invalidity, and survivors' insurance. The reports are followed by a brief account of the discussions during the working sessions of the conference and the volume concludes with the recommendations adopted and the list of participants.

\section{Secretaryship of the Institute}

MEMBERs of the Institute will be sorry to learn that Mrs. Wolfe resigned the Secretaryship at the end of November 1969. In sharing the Officers' regret that we shall no longer benefit from her valuable and much appreciated contribution to our work over the past eight years, they will join in wishing her every happiness. She is expecting a baby early in the New Year and will be moving to New York with her husband who is taking up a post there.

The Chairman has approved the appointment of Mrs. Wendy Hardcastle as Secretary of the Institute from December 1969 .

\section{QUARTERLY CURRENT BIBLIOGRAPHY AND NOTES AND NEWS}

The Bibliography of Current Publications and the Notes and News Section, published quarterly in Africa, are also issued separately for filing and reference. Printed on one side of the paper, the individual items may be put on cards for cataloguing.

Annual subscription for four issues:

Bibliography: 15 s. ( $\$ 1.95 ; F$ ro) post free.

Notes and News: i gs. ( $\$ 1.95 ; F$ ro) post free.

Back issues are available from January 1966. 